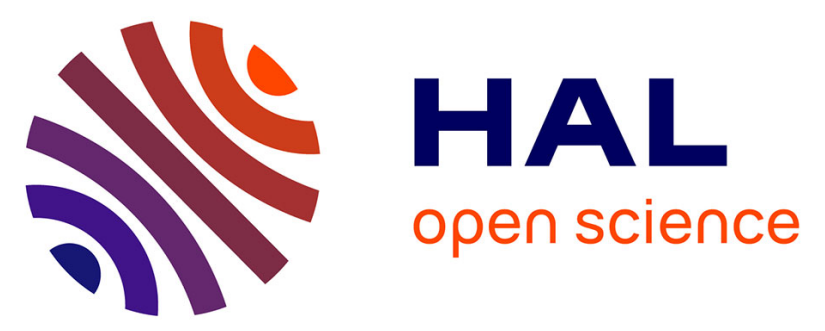

\title{
Nonconventional Three-Component Hierarchical Host-Guest Assembly Based on Mo-Blue Ring-Shaped Giant Anion, gamma-Cyclodextrin, and Dawson-type Polyoxometalate
}

Mhamad Aly Moussawi, Mohamed Haouas, Sébastien Floquet, William E. Shepard, Pavel A. Abramov, Maxim N. Sokolov, Vladimir P. Fedin, Stéphane Cordier, Anne Ponchel, Eric Monflier, et al.

\section{- To cite this version:}

Mhamad Aly Moussawi, Mohamed Haouas, Sébastien Floquet, William E. Shepard, Pavel A. Abramov, et al.. Nonconventional Three-Component Hierarchical Host-Guest Assembly Based on Mo-Blue RingShaped Giant Anion, gamma-Cyclodextrin, and Dawson-type Polyoxometalate. Journal of the American Chemical Society, 2017, 139 (41), pp.14376-14379. 10.1021/jacs.7b08058 . hal-01631922

HAL Id: hal-01631922

https://hal-univ-rennes1.archives-ouvertes.fr/hal-01631922

Submitted on 24 Jan 2018

HAL is a multi-disciplinary open access archive for the deposit and dissemination of scientific research documents, whether they are published or not. The documents may come from teaching and research institutions in France or abroad, or from public or private research centers.
L'archive ouverte pluridisciplinaire HAL, est destinée au dépôt et à la diffusion de documents scientifiques de niveau recherche, publiés ou non, émanant des établissements d'enseignement et de recherche français ou étrangers, des laboratoires publics ou privés. 


\title{
Nonconventional Three-Component Hierarchical Host-Guest Assembly Based on Mo-Blue Ring-Shaped Giant Anion, $\gamma$-Cyclodextrin and Dawson-type Polyoxometalate
}

\author{
Mhamad Aly Moussawi, ${ }^{\dagger}$ Mohamed Haouas, ${ }^{\dagger}$ Sébastien Floquet, ${ }^{\dagger}$ William E. Shepard, ${ }^{\dagger}$ Pavel A. \\ Abramov,,${ }^{\ddagger}$ Maxim N. Sokolov,,${ }^{f}{ }^{\mp}$ Vladimir P. Fedin, $,{ }^{f},{ }^{\circledR}$ Stéphane Cordier, ${ }^{\S}$ Anne Ponchel, ${ }^{\ddagger}$ Eric \\ Monflier, ${ }^{\ddagger}$ Jérôme Marrot, ${ }^{*, \dagger}$ and Emmanuel Cadot ${ }^{*, \dagger}$
}

† Institut Lavoisier de Versailles UMR 8180, UVSQ, Université Paris-Saclay, 78035 Versailles, France.

$\int$ Synchrotron SOLEIL, L'Orme des Merisiers, Saint-Aubain BP 48, 91192 Gif-sur-Yvette CEDEX, France.

f Nikolaev Institute of Inorganic Chemistry SB RAS, Novosibirsk State University, Novosibirsk, 63009o, Russia.

$£$ Novosibirsk State University, Novosibirsk, 630090, Russia.

$\S$ Institut des Sciences Chimique de Rennes UMR 6226, Université de Rennes 1, Rennes, France.

‡ Université Artois, CNRS, Centrale Lille, ENSCL, Université de Lille, UMR 8181, Unité de Catalyse et Chimie du Solide, 62300 Lens, France

\section{Supporting Information Placeholder}

\begin{abstract}
In this communication, we report on a noteworthy hybrid supramolecular assembly built from three functional components hierarchically organized through non-covalent interactions. The one-pot synthesis procedure leads to the formation of large Mo-blue ring-shaped anion $\left\{\mathrm{Mo}_{154}\right\}$ which contains the supramolecular adduct based on the symmetric encapsulation of the Dawson-type $\left[\mathrm{P}_{2} \mathrm{~W}_{18} \mathrm{O}_{62}\right]^{6-}$ anion by two $\gamma$-cyclodextrin units. Such a nanoscopic onion-like structure, noted $\left[\mathrm{P}_{2} \mathrm{~W}_{18} \mathrm{O}_{62}\right] @ 2 \gamma-$ $\mathrm{CD}\left\{\mathrm{Mo}_{154}\right\}$ has been characterized by single-crystal X-ray diffraction thus demonstrating the capability of the giant inorganic torus to develop relevant supramolecular chemistry, probing the strong affinity of the inner and outer faces of the $\gamma-C D$ for the polyoxometalate surfaces. Furthermore, interactions and behavior in solution have been studied by multinuclear NMR spectroscopy which supports specific interactions between $\gamma-C D$ and POM units. Finally, the formation of this three-component hybrid assembly from one-pot procedure, in water and using nearly stoichiometric conditions is discussed in terms of the driving forces orchestrating this highly efficient multi-level recognition process.
\end{abstract}

Supramolecular chemistry dates back to the late 196o's and 1970's from the pioneering work of Pedersen, ${ }^{1,2} \mathrm{Cram}^{3}$ and Lehn. ${ }^{4}$ Their contributions have led to the development of concepts allowing fabrication of gigantic host-guest supramolecular materials with increased

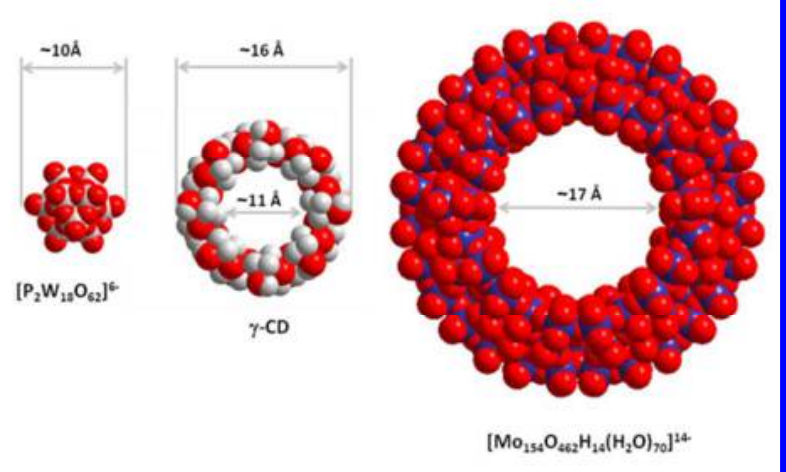

Figure 1. Space-filling representation showing size-matching between host and guest components involved within hierarchical supramolecular assembly.

complexity and functionalities, ${ }^{5}$ that arise from a set of complementary noncovalent interactions such as hydrophobic, coulombic, ion-dipole, dipole-dipole or hydrogen bonding. ${ }^{6}$ Thus, self-assembled mesmerizing supramolecular architectures are able to promote a wide range of chemical and physical events that encompass electron carriers, energy transfer, binding and release of substrates or ion transportation. ${ }^{7}$

In context, polyoxometalates (POMs) represent a unique class of all-inorganic metal-oxygen anionic clusters, which exhibit remarkable physical-chemical properties in relationship with their vast structural diversity. ${ }^{8}$ Actually, this class of molecular objects offers huge potentialities for 
their use as sub-components in supramolecular hybrid materials ${ }^{9,10}$ owing to their specific shapes such as torus, ${ }^{11}$ hollow spheroidal capsule, ${ }^{12,13}$ cylinder or cubic box. ${ }^{14,15}$ POMs interact also with biological matter that confer biological activities. ${ }^{16}$ Recent results shed light on the origins of primary interactions between POMs and specific patches of proteins that include cooperation of non-specific interactions, driven by fine balancing between electrostatic and hydrophobic effects directly related to the charge and the surface area of the POM species. ${ }^{17}$ Big wheels deriving from molybdenum blue chemical system ${ }^{18,19,20}$ exhibit typical toroidal architectures lining a large shape-persistent cavity able to encapsulate large organic substrates such as porphyrins, ${ }^{21}$ or inorganic polynuclear clusters. ${ }^{22}$ However, taking into account the large diameter of these available cavities, supramolecular properties of these ring-shaped compounds remain unexploited.

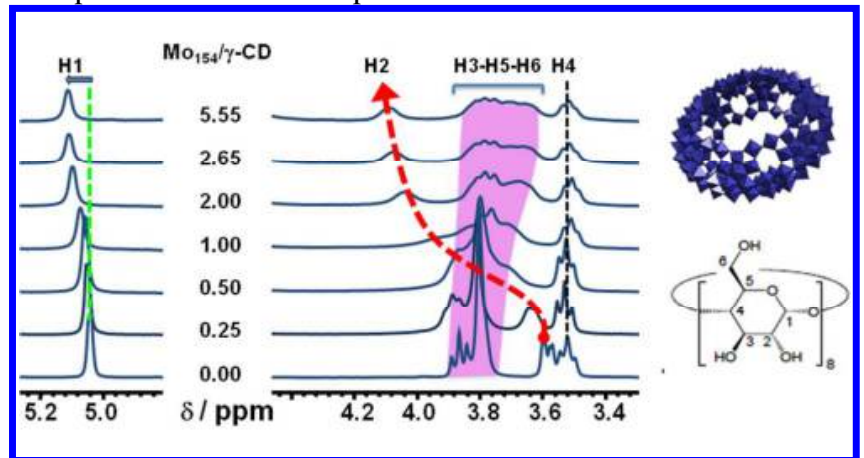

Figure 2. Selected ' $\mathrm{H}$ NIMR spectra (400 MHz, $298 \mathrm{~K}, \mathrm{D}_{2} \mathrm{O}, 3$ $\mathrm{mM})$ of $\gamma$-CD in the presence of different equivalents of $\left\{\mathrm{Mo}_{154}\right\}$ ring-shaped anion. The marked deshielding effect occurring for the outer $\mathrm{H}_{2}$ nuclei suggests the inclusion complex formation $\{\gamma$ $\left.\mathrm{CD} @ \mathrm{Mo}_{154}\right\}$ involving the secondary face of the $\gamma-\mathrm{CD}$ and the large inner cavity of the Mo-blue wheel.

Herein we report the first hybrid hierarchical assembly based on the $\left[\mathrm{Mo}_{154} \mathrm{O}_{462} \mathrm{H}_{14}\left(\mathrm{H}_{2} \mathrm{O}\right)_{70}\right]^{14-}$ molecular wheel (abbreviated $\left\{\mathrm{Mo}_{154}\right\}$ hereafter $){ }^{18}$ which includes in its central cavity the supramolecular adduct built from the archetypical Dawson polyoxometalate $\left[\mathrm{P}_{2} \mathrm{~W}_{18} \mathrm{O}_{62}\right]^{6-}$ capped by two $\gamma$-cyclodextrins (see Figure 1). $\gamma$-cyclodextrin $\mathrm{C}_{48} \mathrm{H}_{80} \mathrm{O}_{40}$ (noted $\gamma$-CD hereafter) has been selected as organic unit for its specific ring-shaped architecture and size-matching with the inward dimension of the large hole delimited by the ringshaped $\left\{\mathrm{Mo}_{154}\right\}$ anion (see Figure 1). Besides, cyclodextrins are distinguished as prominent synthetic receptor, ${ }^{23},{ }^{10}$ useful for wide applications in many fields of science such as nanotechnology, ${ }^{24}$ pharmaceutics ${ }^{25}$ or medicine. ${ }^{26}$

The interactions of $\gamma$-CD with $\left\{\mathrm{Mo}_{154}\right\}$ were investigated by ${ }^{1} \mathrm{H}$ NMR in $\mathrm{D}_{2} \mathrm{O}$. Especially, we witnessed a pronounced complexation-induced deshielding of the $\mathrm{H}_{2}$ proton $(\Delta \delta \sim+$ $0.5 \mathrm{ppm}$ ) (see Figure 2), which is located outside the cavity near the secondary hydroxyl rim. Similar effect, but in a lower extent was observed on the outer $\mathrm{H} 1$ proton while the $\mathrm{H}_{4}$ proton appears quite unaffected. Furthermore, the assignment of the most affected signal to the $\mathrm{H} 2$ proton has been confirmed by ${ }^{1} \mathrm{H}$ NOESY NMR experiment (see Supporting Information, Figure $\mathrm{S}_{3}, \mathrm{~S}_{5}$ ).

These NMR results suggest that $\gamma$-CD penetrates deeply into the large cavity of the $\left\{\mathrm{Mo}_{154}\right\}$ anion, leading to a deshielding effect for the outer protons in contact with the inner oxygen of the $\left\{\mathrm{Mo}_{154}\right\}$ ring-shaped anion. In addition, the formation of supramolecular adduct involving $\left\{\mathrm{Mo}_{154}\right\}$ and $\gamma-\mathrm{CD}$ is also nicely supported by ${ }^{1} \mathrm{H}$ DOSY NMR experiments, showing a clear monotonous decrease of the self-diffusion coefficient of the $\gamma$-CD from 280 for the free-solvated species to $106 \mu \mathrm{m}^{2} . \mathrm{s}^{-1}$ in the presence of $\left\{\mathrm{Mo}_{154}\right\}$ (Figure $\mathrm{S}_{4}, \mathrm{SI}, \S_{5}$ ).

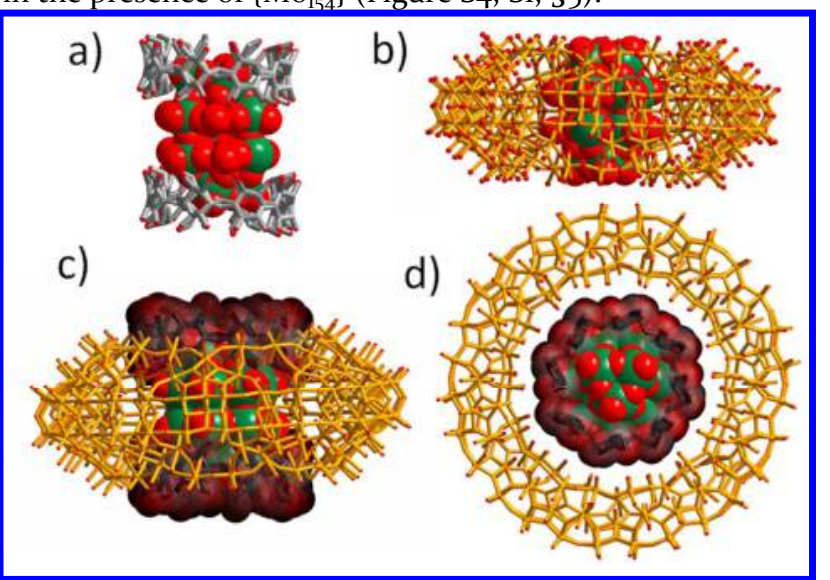

Figure 3. Mixed representations of the supramolecular hierarchical compound $1 \quad\left\{\left[\mathrm{P}_{2} \mathrm{~W}_{18} \mathrm{O}_{62}\right] @ 2 \gamma-\mathrm{CD} @ \mathrm{Mo}_{154}\right\}$ : a) highlight of the inner adduct built from a Dawson anion $\left[\mathrm{P}_{2} \mathrm{~W}_{18} \mathrm{O}_{62}\right]^{6-}$ capped by two $\gamma-\mathrm{CD}$ tori. b) representation showing the deep inclusion of the Dawson anion within the large inner cavity of the Mo-blue ring-shaped anion. c) Side and d) Top views of the hybrid supramolecular adduct showing the hierarchical organization between three components with the Dawson anion at the center (green and red space-filling spheres) capped by two $\gamma$-CD (wires and transparent space-filling spheres) encaged into the large $\left\{\mathrm{Mo}_{154}\right\}$ torus (yellow sticks).

A more complex scenario has been examined by introducing $\left[\mathrm{P}_{2} \mathrm{~W}_{18} \mathrm{O}_{62}\right]^{6-}$ species as a third component able to interact with the inner face of the $\gamma-\mathrm{CD}$. After exploring and repeating different synthetic approaches as well some analytical test procedures, it became evident that selected POMs, $\gamma-\mathrm{CD}$ and $\left\{\mathrm{Mo}_{154}\right\}$ ring-shaped anion were able to interact together to produce a chemically pure assembly. Lastly, one-pot synthesis allowed isolating well-shaped three-component single crystals with good yield $(\sim 40 \%)$. The synthesis was merely inspired from that previously reported by Müller et $a .^{20}$ and consists of acidification until $\mathrm{pH}=1$ of $\mathrm{Na}_{2} \mathrm{MoO}_{4}$ aqueous solution under reducing conditions (sodium dithionite was used as reducing agent) in the presence of $\gamma$ $\mathrm{CD}$ and Dawson anion $\left[\mathrm{P}_{2} \mathrm{~W}_{18} \mathrm{O}_{62}\right]^{6-}$ in ratios Mo : $\gamma-\mathrm{CD}$ : $\left[\mathrm{P}_{2} \mathrm{~W}_{18} \mathrm{O}_{62}\right]^{6-}=154: 4: 1$ (see SI, §2 for further details about synthesis conditions). Formation of three-component singlecrystals with abbreviated formula $\mathrm{Na}_{15} \mathrm{~K}_{3} \mathrm{H}_{2}\left[\left\{\mathrm{Mo}_{154}\right\}\left(\mathrm{P}_{2} \mathrm{~W}_{18} \mathrm{O}_{62}\right)(\gamma-\mathrm{CD})_{4}\right] \cdot 225 \mathrm{H}_{2} \mathrm{O}$ (noted 1 hereafter) was readily achieved through slow evaporation of the resulting solution. X-Ray diffraction analysis of $\mathbf{1}$ gave a structural model which reveals a striking three-component supramolecular adduct arranged within a remarkable hierarchical organization, wherein the Dawson anion $\left[\mathrm{P}_{2} \mathrm{~W}_{18} \mathrm{O}_{62}\right]^{6-}$ appears capped by two $\gamma$-CDs both interacting symmetrically with the two opposite caps of the anion (see Figure 3a). Such a type of arrangement resembles to some extent that observed by Stoddart et al. with the Keggin-type anion encapsulated by two $\gamma-\mathrm{CD} .^{10}$ Furthermore, this supramolecular assembly appears embedded deeply within 
the large inner cavity of the $\left\{\mathrm{Mo}_{154}\right\}$ torus to give the nonconventional $\quad\left(\left[\mathrm{P}_{2} \mathrm{~W}_{18} \mathrm{O}_{62}\right] @ 2 \gamma-\mathrm{CD} @\left\{\mathrm{Mo}_{154}\right\}\right) \quad$ inclusion complex. Actually, the two inner $\gamma$-CDs appear severely disordered within the $\left\{\mathrm{Mo}_{154}\right\}$ torus but we succeeded to rebuild backbones of the two inner $\gamma$-CDs from electronic density. This disorder scheme appears quite consistent with usual geometrical parameters and then give reliable arguments to demonstrate the steric host-guest compatibility between $\gamma$-CDs and the $\left\{\mathrm{Mo}_{154}\right\}$ torus (see Figure S2, SI §4.3), but it would be highly speculative to give any firm conclusion about the interacting rim of the $\gamma$-CD i.e. secondary or primary $\mathrm{CD}$ faces directed toward the cavity center of the $\left\{\mathrm{Mo}_{154}\right\}$ anion. Nevertheless, the proposed structural model allows identifying a network of convergent hydrogen bonds which involves hydroxo groups of the $\gamma-\mathrm{CD}$ and either some oxygen atoms of the $\left\{\mathrm{Mo}_{154}\right\}$ outer host or those of the $\left[\mathrm{P}_{2} \mathrm{~W}_{18} \mathrm{O}_{62}\right]^{6-}$ inner guest (see Figure $\mathrm{S}_{2}$, SI $\S_{4.3}$ ). These intermolecular hydrogen-bonding interactions give rise to quite short $0 \cdots 0$ contacts observed in the $275-2,20 \AA$ range.

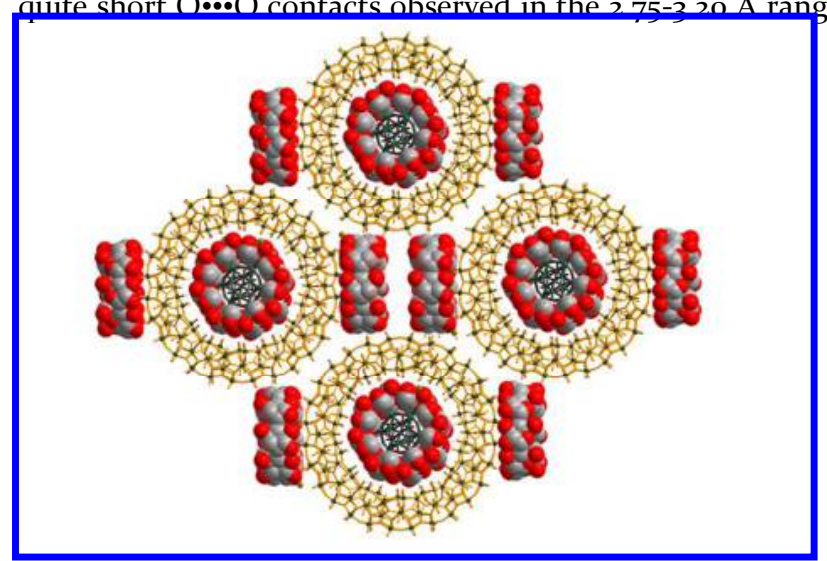

Figure 4. Selected view of 1 showing large holes delimited by the $\{$ Mo154\} packing which are filled by two outer $\gamma$-CD units.

Finally, X-Ray structural analysis of $\mathbf{1}$ supported by its elemental analysis revealed two additional $\gamma$-CD units per $\left\{\mathrm{Mo}_{154}\right\}$ unit literally stuck on the outward surface of the $\left\{\mathrm{Mo}_{154}\right\}$ ring-shaped anion and located within holes delimited by the $\left\{\mathrm{Mo}_{154}\right\}$ packing (see Figure 4 ). Still here, these $\gamma$-CD units appear disordered and no definitive conclusion can be given about the type of face interacting directly with the $\left\{\mathrm{Mo}_{154}\right\}$ surface. However, such a result demonstrates that $\gamma$ $\mathrm{CD}$ unit is able to interplay with $\left\{\mathrm{Mo}_{154}\right\}$ anion either through highly specific host-guest recognition process with its large inner cavity or through less specific interactions involving its large exposed surface area. Actually, it should be worth noting that composition of $\mathbf{1}$ corresponds precisely to the composition of the synthetic mixture. Further details about the X-ray diffraction analysis are given in Supporting Information (§1 and §4).

Preliminary multinuclear NMR studies (including $\mathrm{1D}$ and DOSY experiments) in aqueous solution have been carried out on this three-component chemical system. The ${ }^{31} \mathrm{P}$ NMR spectrum of 1 ( $5 \mathrm{mmol} . \mathrm{L}^{-1}$ in aqueous solution) shown in Figure 5 contains in addition to the resonance attributed to solvated $\left[\mathrm{P}_{2} \mathrm{~W}_{18} \mathrm{O}_{62}\right]^{6-}$ observed at $\delta=-12.34 \mathrm{ppm}$, three additional signals at -12.43, -12.53 (shoulder) and -12.69 ppm (deconvolution is shown in Supporting Information, Figure $\mathrm{S}_{5}, \mathrm{~S}_{5}$ ). The presence of shielded ${ }^{31} \mathrm{P}$ nuclei must be related to

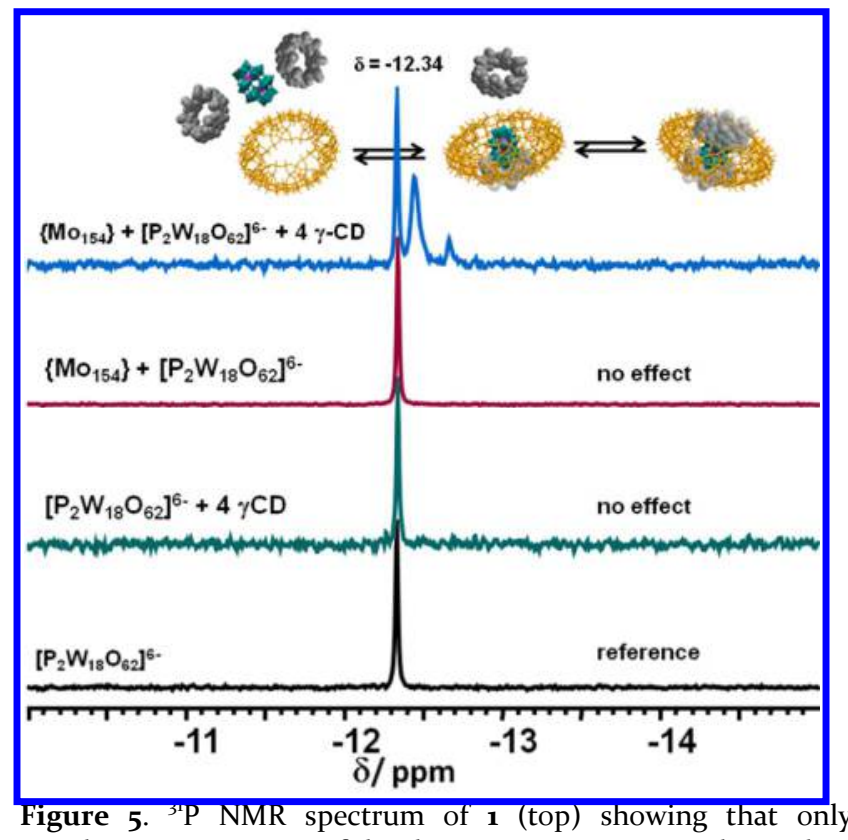

simultaneous presence of the three components provokes a clear change of ${ }^{31} \mathrm{P}$ NMR spectrum. The presence of four ${ }^{31} \mathrm{P}$ NMR signals with $32: 52: 8: 8$ intensity ratio is consistent with $\left[\mathrm{P}_{2} \mathrm{~W}_{18} \mathrm{O}_{62}\right]^{6-}$ ion as solvated ion $(\delta=-12.34 \mathrm{ppm})$ or as central guest species into the three-component assemblies $(\delta=-12.43$, 12.53 and $-12.69 \mathrm{ppm})$. The presence of three shielded ${ }^{31} \mathrm{P}$ resonances should be interpreted as slow equilibria occurring between bicapped and monocapped guest species as depicted in scheme inserted on the upper ${ }^{31} \mathrm{P}$ NMR spectrum.

the screening effect of the $\left\{\mathrm{Mo}_{154}\right\}$ host onto the deeply embedded $\left[\mathrm{P}_{2} \mathrm{~W}_{18} \mathrm{O}_{62}\right]^{6-}$ guest. Such a shielding effect is usually observed for any guest species included within the inner cavity of metal-oxo shell. ${ }^{27}$ However, the presence of these three low-frequency signals suggests that $\left[\mathrm{P}_{2} \mathrm{~W}_{18} \mathrm{O}_{62}\right]^{6-}$ species are involved within slow dynamic processes which could correspond to the successive release of the inner $\gamma$-CD component from $\mathbf{1}$ (observed at $-12.43 \mathrm{ppm}$ ) leading to the monocapped guest species $(\delta=-12.53$ and $-12.69 \mathrm{ppm})$ and to the solvated species $(\delta=-12.34 \mathrm{ppm})$, respectively. Furthermore, the attribution of the low-frequency signals to the supramolecular three-component system has been confirmed by ${ }^{31} \mathrm{P}$ DOSY NMR (see Figure $\mathrm{S}_{7}$, SI §5.4). The species involved in the ternary hierarchical system (observed at $-12.43 \mathrm{ppm}$ ) exhibit a very low diffusion coefficient $D=73$ $\mu \mathrm{m}^{2} / \mathrm{s}$, while the solvated interacting species at $\delta=-12.34$ $\mathrm{ppm}$ is characterized by an intermediate $D$ value of $181 \mu \mathrm{m}^{2} / \mathrm{s}$ compared to the same species without any interaction in pure solvent $\left(D=325 \mu \mathrm{m}^{2} / \mathrm{s}\right)$. Such an intermediate $D$ value is not only due to slow exchange processes between free and embedded species (see SI \$5.4, Figure S6) but also to interactions between solvated $\left\{\mathrm{P}_{2} \mathrm{~W}_{18} \mathrm{O}_{62}\right]^{6-}$ species and outer $\gamma$-CDs which form labile aggregates. ${ }^{28}$ Besides, ${ }^{1} \mathrm{H}$ NMR of $\mathbf{1}$ reveals that formation of three-component system leads to complex ${ }^{1} \mathrm{H}$ NMR spectra characterized by significant line width broadening and by the appearance of many new ${ }^{1} \mathrm{H}$ NMR resonances (see Figures S8-S9, SI \$5.3). In few lines, these NMR results are consistent with dynamically slow equilibria in $\mathrm{D}_{2} \mathrm{O}$ solution involving deeply embedded components through the inner and outer faces of $\gamma$-CD tori. Besides, ${ }^{1} \mathrm{H}$ DOSY NMR revealed that these new resonances are characterized by a significant low self-diffusion $(D=106$ 
$\left.\mu \mathrm{m}^{2} . \mathrm{s}^{-1}\right)$ in agreement with the nanoscopic dimension of the onion-like supramolecular assembly (see Figure S4, SI §5.5). These preliminary NMR characterizations constitute bases for further investigations of this exciting supramolecular chemical system.

In summary, we report the discovery of a remarkable hierarchical assembly, built from three functional components specifically formed through a one pot procedure. It transpires that the recognition processes and the related contributors to the effective driving force must be strongly efficient. Actually, formation of this onion-like supramolecular architecture in aqueous solution should be suspected highly improbable because the three individual functional subunits are highly soluble in water and thus considered as hydrophilic species. Generic driving forces leading to this multi-level assembly could arise from a pronounced "chaotropic" effect that remains not well understood with polyoxometalates, ${ }^{29}$ especially for those ranging within nanoscopic dimension. Given the scope of this area, it becomes palpable that such a preliminary study should open new avenues toward exciting, extensive and challenging physical-chemistry.

\section{ASSOCIATED CONTENT}

\section{Supporting Information}

General methods (§1); syntheses (§2); FT-IR spectra (§3); single crystal X-Ray diffraction including crystallographic parameters (Table $\mathrm{S}_{1}$ ) and additional figures $\left(\S_{4}\right)$; NMR data (§5), "This material is available free of charge via the Internet at http://pubs.acs.org."

\section{AUTHOR INFORMATION}

\section{Corresponding Author}

emmanuel.cadot@uvsq.fr

jerome.marrot@uvsq.fr

\section{Notes}

The authors declare no competing financial interests.

\section{ACKNOWLEDGMENT}

The Authors gratefully acknowledge financial support from LIA-CNRS CLUSPOM and LABEX CHARMMMAT. This work was also supported by University of Versailles Saint Quentin, CNRS and Région Ile de France through DIM Nano K. We are also grateful to Mme Meryem Najib for experimental studies

\section{REFERENCES}

(1) Pedersen, C. J. J. Am. Chem. Soc. 1967, 89, 2495

(2) Pedersen, C. J. I. Am. Chem. Soc. 1967, 89, 7017.

(3) Cram, D. J.; Kaneda, T.; Helgeson, R. C.; Lein, G. M. L. Am. Chem. Soc. 1979, 101, 6752.

(4) Lehn, J. M. Anqew. Chem. Int. Ed. 1990, 29, 1304.

(5) Vickers, M. S.; Beer, P. D. Chem. Soc. Rev. 2007, 36, 211.

(6) Pluth, M. D.; Raymond, K. N. Chem. Soc. Rev. 2007, 36, 161.

(7) (a) Suh, J. Adv. Supramol. Chem. 200o, 6, 245-286.; (b) Fersht, A. R. Structure and Mechanism in Protein Science, W. H. Freeman, new York, 2000.
(8) (a) Pope, M. T.; Müller, A. Anqew. Chem.-Int. Edit. Enql. 1991, 30, 34. (b) Special issue on polyoxometalates: Cronin L. and Müller A. Chem. Soc. Rev., 2012, 41, 7333; (c) Dolbecq, A.; Dumas, E.; Mayer, C. R.; Mialane, P. Chem. Rev. 2o10, 110, 6oog; (d) Hill, C. L. Chem. Rev. 1998, 98, 1; (e) Pope, M. T. Heteropoly and IsopolyOxometalates; Springer-Verlag: New York, 1983.

(9) Fang, X.; Kögerler, P.; Isaacs, L.; Uchida, S.; Mizuno, N. L. Am. Chem. Soc. 2009, 131, 432.

(10) Wu, Y. L.; Shi, R. F.; Wu, Y. L.; Holcroft, J. M.; Liu, Z. C.; Frasconi, M.; Wasielewski, M. R.; Li, H.; Stoddart, J. F. L. Am. Chem. Soc. 2015, 137, 4111.

(11) (a) Contant, R.; Tézé, A. Inorg. Chem. 1985, 24, 4610-4614.

POMs; (b) A. Müller, A.; Krickemeyer, E.; Meyer, J.; Bögge, H.; Peters, F.; Plass, W.; Diemann, E.; Dillinger, S.; Nonnenbruch, F.; Randerath, M.; Menke, C. Angew. Chem. Int. Ed. Engl. 1995, 34 , 2122.

(12) (a) Müller, A.; Peters, F.; Pope, M. T.; Gatteschi, D. Chem. Rev. 1998, 98, 239. (b) Müller, A.; Kögerler, P.; Dress, A. W. M. Coord. Chem. Rev. 2001, 222, 193. (c) Müller, A.; Kögerler, P.; Kuhlmann, C. Chem.Commun. 1999, 1347. (d) Cronin, L.; Beugholt, C.; Krickemeyer, E.; Schmidtmann, M.; Bögge, H.; Kögerler, P.; Luong, T. K. K.; Möller, A. Anqew. Chem., Int. Ed. 2002, 41, 2805-2808.

(13) (a) Watfa, N. ; Melgar, D. ; Haouas, M. ; Taulelle, F. ; Hijazi, A. ; Naoufal, D. ; Avalos, J. B. ; Floquet, S. ; Bo, C. ; Cadot, E. J. Am. Chem. Soc. 2015, 137, 5845. (b) Müller, A.; Das, S.K.; Kögerler, P.; Bögge, H.; Schmidtmann, M.; Trautwein, A. X.; Schünemann, V.; Krickemeyer, E.; Preetz, W. Anqew. Chem. Int. Ed. 20oo, 39, 34133417.

(14) F. Banani, F.; Floquet, S. ; Leclerc-Laronze, N. ; Haouas, M. ; Taulelle, F. ; Marrot, J. ; Kögerler, P. ; Cadot, E L. Am. Chem. Soc. 2012, 134, 19342.

(15) Korenev, V.S.; Boulay, A. G.; Haouas, M. ; Bannani, F.; Fedin, V. P.; Sokolov, M. N.; Terazzi, E.; Garai, S.; Müller, A.; Taulelle, F.; Marrot, J.; Leclerc, N. ; Floquet, S. ; Cadot, E. Chem.Eur.-J. 2014, 20 , 3097.

(16) (a) Judd, D. A.; Nettles, J. H.; Nevins, N.; Snyder, J. P.; Liotta, D. C.; Tang, J.; Ermolieff, J.; Schinazi, R. F.; Hill, C. L. J. Am. Chem. Soc 2001, 123, 886-897. (b) Sarafianos, S. G.; Kortz, U.; Pope, M. T.; Modak, M. I. Biochem I, 1996, 319, 619-626. (c) Absillis, G.; Cartuyvels, E.; Van Deun, R.; Parac-Vogt, T. N. J. Am. Chem. Soc. 2008, 130, 17400. (d) Luong, T. K. N.; Shestakova , P.; Mihaylov, T. T.; Absillis, G.; Pierloot, K.; Parac-Vogt, T. N. Chem. Eur. J. 2015, 21, 4428.

(17) Solé-Daura, A.; Goovaerts, V.; Stroobants, K. ; Absillis, G.; Jiménez-Lozano, P.; Poblet, J. M. ; Hirst, J. D. ; Parac-Vogt, T. ; Carbò, J. J. Chem. Eur. J. 2016, 22, 15280.

(18) A. Müller, A.; Shah, S. Q. N.; Bögge, H.; Schmidtmann, M. Nature, 1999, 397, 50

(19) Müller, A.; Gouzerh, P. Chem. Soc. Rev. 2012, 41, 7431.

(20) Müller, A.; Meyer, J.; Krickemeyer, E.; Diemann, E. Anqew. Chem. Int. Ed. 1996, 35, 1206.

(21) Tsuda, A.; Hirahara, E.; Kim, Y. S.; Tanaka, H.; Kawai, T.; Aida, T. Angew. Chem.-Int. Edit. 2004, 43, 6327.

(22) Miras, H. N.; Cooper, G. J. T.; Long, D. L.; Bögge, H.; Müller, A.; Streb, C.; Cronin, L. Science 2010, 327, 72.

(23) Assaf, K. I.; Ural, M. S.; Pan, F. F.; Georgiev, T.; Simova, S.; Rissanen, K.; Gabel, D.; Nau, W. M. Anqew. Chem.-Int. Ed. 2015, 54, 6852.

(24) Chen Y.; Liu, Y. Chem. Soc. Rev., 2010, 39, 495.

(25) Davis, M. E.; Brewster, M. E. Nat. Rev. Druq. Disc. 2004, 3, 1023. (26) Arima, H. ; Motoyama, K. ; Higashi, T. Therapeutic Delivery, 2017, 8, 215

(27) Schäffer, C.; Merca, A.; Bögge, H.; Todea, A. M.; Kistler, M. L.; Liu, T.; Thouvenot, R.; Gouzerh, P.; Müller, A. Angew. Chem. Int. Ed. 2009, 48,149

(28) Moussawi, M. A.; Leclerc-Laronze, N.; Floquet, S.; Abramov, P. A.; Sokolov, M. N.; Cordier, S.; Ponchel, A.; Monflier, E.; Bricout, H.; Landy, D.; Haouas, M.; Marrot, J.; E. Cadot I. Am. Chem. Soc., 2017, 139,12793-12803.

(29) Kobayashi, D.; Nakahara, H.; Shibata, O.; Unoura, K.; Nabika, H. J. Phys. Chem. C, 2017, J. Phys. Chem. C, 2017, 121, 12895. 


\section{Page 5 of 5}

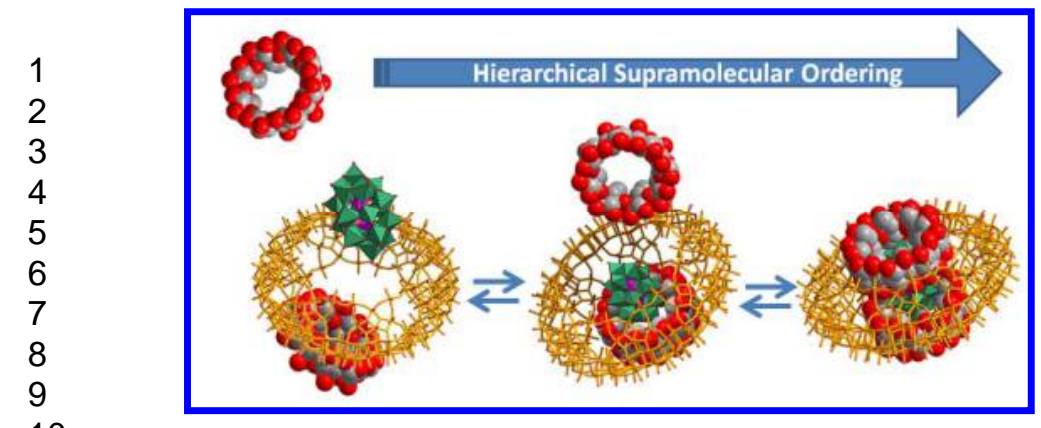

Table Of Content

13

14

15

16

17

18

19

20

21

22

23

24

25

26

27

28

29

30

31

32

33

34

35

36

37

38

39

40

41

42

43

44

45

46

47

48

49

50

51

52

53

54

55

56

57

58

59

60 